\title{
Using a chlorophyll meter to estimate tea leaf chlorophyll and nitrogen contents
}

\author{
Z.A. Liu, J.P. Yang*, Z.C. Yang \\ College of Environmental and Resource Sciences, Zhejiang University, Hangzhou 310058 Zhejiang, P. R. \\ China. *Corresponding author: jpyang@zju.edu.cn
}

\begin{abstract}
A chlorophyll meter can conveniently estimate foliar chlorophyll and nitrogen $(\mathrm{N})$ contents in many species. The objective of this study was to evaluate the utility of a chlorophyll meter to inform nitrogen fertilization rates of tea (Camellia sinensis L.) at different places and times. Plot-scale $(5 \times 20 \mathrm{~m})$ experiments with three replications were conducted in 2010. Each plot was treated with $248 \mathrm{~kg}$ pure $\mathrm{N} \mathrm{ha}^{-1}$ per year as urea. At the same time, a field-scale ( $32 \mathrm{ha}$ ) experiment, with the same fertilization rate, was conducted at the same plantation. Tea leaves were sampled in August and November and analyzed with a chlorophyll meter in situ and in the lab. The chlorophyll and nitrogen contents and chlorophyll meter (SPAD) readings of tea leaves in August were greater than in November, and plot-scale values were greater than field-scale values. SPAD readings could estimate the chlorophyll content of tea leaves regardless of temporal and spatial considerations. However, space and time must be considered when using SPAD readings to estimate the nitrogen content of tea leaves.
\end{abstract}

Keywords: chlorophyll indicator, nitrogen nutrition, nitrogen partitioning, SPAD reading, tea leaves. 


\section{Introduction}

Nitrogen $(\mathrm{N})$ is the major nutrient affecting tea growth, yield, and quality. Applying $\mathrm{N}$ fertilizer can substantially increase the production of new shoots and the content of functional compounds, such as amino acids (Venkatesan and Ganapathy, 2004; Kamau et al., 2008). The northwest of Zhejiang Province is one of the most intensively managed tea-growing areas in China. To maximize yield, local tea growers often use great quantities of $\mathrm{N}$ fertilizers three to four times a year. Excessive $\mathrm{N}$ is quickly lost from tea fields in runoff, which not only lowers the fertilization efficiency, but also causes environmental pollution (Jaynes et al., 2001; Zvomuya et al., 2003). Therefore, timely and appropriate nitrogen application would be important to improving yield and quality as well as reducing environmental pollution (Errebhi et al., 1998; Costa et al., 2001). However, a rapid method to evaluate the $\mathrm{N}$ status of tea plants is lacking.

Conventional methods of evaluating crop $\mathrm{N}$ status are time-consuming and complicated. A chlorophyll (Chl) meter is a small and portable instrument that can non-destructively and rapidly evaluate crop $\mathrm{N}$ status. Such meters have been used to estimate foliar $\mathrm{Chl}$ and $\mathrm{N}$ content in various species, such as rice (Huang et al., 2008), wheat (Le Bail et al., 2005), beans (Abdelhamid et al., 2003), and fruit trees (Schaper and Chacko, 1991). However, the literature does not address whether a Chl meter can evaluate $\mathrm{Chl}$ and/or N contents in tea plants.

A Chl meter estimates in situ relative foliar $\mathrm{Chl}$ levels by measuring absorption at 650 and $940 \mathrm{~nm}$ wavelengths. Photosynthetic proteins account for more than half of the $\mathrm{N}$ in a crop leaf, and crop foliar $\mathrm{Chl}$ content is significantly correlated with foliar $\mathrm{N}$ content (Evans, 1989). Therefore, the SPAD-502 chlorophyll meter (SPAD) reading should reflect foliar $\mathrm{N}$ status (Denuit et al., 2002; Le Bail et al., 2005). The relationship between SPAD readings and foliar $\mathrm{Chl}$ or $\mathrm{N}$ for other crops has been intensively studied and is known to be affected by plant variety (Hoel, 2002), growing conditions (Campbell et al., 1990), sampling point (Chapman and Barreto, 1997), leaf age (Jinwen et al., 2009), and other factors. However, most previous studies were conducted using microscale plot trials, and little information is available at the field scale. Furthermore, we know of no research on how the relationships between $\mathrm{Chl}$ and $\mathrm{N}$ contents and SPAD readings change in space and time.

The aims of this study were to investigate: (1) whether SPAD readings could indicate $\mathrm{Chl}$ and/or N contents; (2) temporal and spatial differences in Chl and $\mathrm{N}$ contents and in SPAD readings; and (3) correlations in space and time between the SPAD and the actual foliar $\mathrm{Chl}$ and $\mathrm{N}$ contents as a measure of the utility of SPAD readings for assessing the $\mathrm{Chl}$ and $\mathrm{N}$ status of tea leaves.

\section{Materials and Methods}

\subsection{Site and experimental treatments}

The experiments were conducted at Hanghzhou experimental tea farm, in Zhejiang province, China (119 $53^{\prime}$ E, $30^{\circ} 23^{\prime} \mathrm{N}$; elevation: $20 \mathrm{~m}$ ). The tea plants used in the experiments were forty years old (Camellia sinensis L. cv. "Jiukeng"). Plot- $\left(5 \times 20 \mathrm{~m}^{2}\right)$ and field-scale (32 ha) experiments were conducted simultaneously. The plot-scale experiments were replicated three times. Tea plants in each plot were treated with $248 \mathrm{~kg}$ pure $\mathrm{N} \mathrm{ha}^{-1}$ per year as urea, with $124 \mathrm{~kg}$ pure $\mathrm{N} \mathrm{ha}^{-1}$ basally applied on May 1 and on October 1, 2010. At the same time, a field-scale experiment was conducted 
with the same fertilizer treatment. All other farm management practices were conducted in the same way.

\subsection{Sampling and measurements}

Tea leaves were sampled on August 1 and November 1 using a grid sampling method. A $2.5 \times 2.5 \mathrm{~m}$ grid was established in the plot experiment, and the field experiment used an $80 \times 80 \mathrm{~m}$ grid that was determined using a global positioning system. There were 16 sampling points in each plot and 50 sampling points in the field. At every point, a composite sample was obtained from 20 fully expanded, current-year mature tea leaves (the fourth or fifth leaf from the apex on each of 20 randomly-sampled shoots per plant) within a 1-m radius of each grid point. A SPAD-502 chlorophyll meter (Minolta Camera Co., Osaka, Japan), was used in situ to estimate chlorophyll content. The SPAD reading of each tea leaf was obtained at three locations: (a) about one-third of the leaf length from the petiole, (b) at the midpoint of leaf, and (c) about one-third of the leaf length from the apex (Lin et al., 2010). At each location, a measurement was taken on both sides of the leaf vein. The six SPAD readings were averaged to provide a single reading per leaf.

Immediately after the SPAD measurements, the sampled leaves were removed from the plant and taken to the lab in an insulated box full of ice. They were either analyzed immediately or frozen $\left(-20^{\circ} \mathrm{C}\right)$ until testing. Five fresh leaves from each sampling point were extracted in $96 \%(\mathrm{v} / \mathrm{v})$ ethanol and the absorbance was measured at 649 and $665 \mathrm{~nm}$ with a spectrophotometer (Fritschi and Ray, 2007). Chlorophyll contents were determined using the method of Arnon (1949).

For foliar nitrogen determination, tea leaves were dried at $105^{\circ} \mathrm{C}$ for 30 minutes to rapidly stop the ac- tivity of polyphenol oxidase and then at $70^{\circ} \mathrm{C}$ until dry weight was constant. Dried tea samples were ground, and foliar $\mathrm{N}$ content was determined by the Dumas combustion method (Rapid N cube, Elementar Analysensysteme, Hanau, Germany) (Jung et al., 2003). Three replicates were taken for each measurement.

\subsection{Data analysis}

SPSS v.17 (SPSS Inc, Chicago, IL, USA) was used for all statistical analyses. Two-way analysis of variance (ANOVA) was used to assess temporal and spatial differences. All statistical analyses were considered significant when $P$-values were $<0.05$.

\section{Results}

\subsection{Temporal variation in chlorophyll and nitrogen contents and $S P A D$ readings}

There were significant temporal differences in the $\mathrm{Chl} a$, Chl $b$, and $\mathrm{N}$ contents of tea leaves, whereas no significant temporal differences were observed in the actual (laboratory-measured) foliar total Chl contents and SPAD readings (Table 1). Foliar Chl $b$ and $\mathrm{N}$ contents in August were significantly higher than in November, while foliar $\mathrm{Chl} a$ contents in August were significantly lower than in November. Chl, Chl $a$, and $\mathrm{Chl} b$ contents and $\mathrm{Ch} 1 / \mathrm{N}$ ratio were significantly positively correlated with SPAD readings $(\mathrm{P}<0.01)$, while the $\mathrm{Chl} a / b$ ratio was significantly negatively correlated with SPAD readings in August and in November (Table 2). In general, the relationships between foliar $\mathrm{Chl}, \mathrm{Chl} / \mathrm{N}$ ratio, and SPAD readings were stronger in August than in November, with the correlation coefficients decreasing from August to November. 
Table 1. SPAD readings and chlorophyll and nitrogen contents measured in tea leaves at plot and field scales in August and November, 2010. There were 16 sampling points at the plot scale $\left(100 \mathrm{~m}^{2}\right)$ and 50 sampling points at the field scale (32 ha). Results from a two-way ANOVA are also shown.

\begin{tabular}{|c|c|c|c|c|c|c|c|}
\hline \multirow{2}{*}{$\begin{array}{l}\text { Foliar in- } \\
\text { dexes }\end{array}$} & \multicolumn{2}{|c|}{ Plot scale $(n=16)$} & \multicolumn{2}{|c|}{ Field scale $(n=50)$} & \multicolumn{3}{|l|}{$\mathbf{P}$} \\
\hline & August & November & August & November & Temporal (T) & Spatial (S) & $\mathbf{T} \times \mathbf{S}$ \\
\hline SPAD reading & $63.04 \pm 4.29$ & $61.08 \pm 5.21$ & $62.78 \pm 4.83$ & $60.92 \pm 5.96$ & ns & ns & ns \\
\hline CV (\%) & 6.81 & 8.53 & 7.69 & 9.78 & & & \\
\hline $\mathrm{Chl}\left(\mathrm{mg} \mathrm{g}^{-1}\right)$ & $2.69 \pm 0.36$ & $2.67 \pm 0.38$ & $2.62 \pm 0.42$ & $2.58 \pm 0.39$ & ns & $\mathrm{ns}$ & ns \\
\hline CV $(\%)$ & 13.38 & 14.23 & 16.03 & 15.12 & & & \\
\hline Chl $a\left(\mathrm{mg} \mathrm{g}^{-1}\right)$ & $1.97 \pm 0.22$ & $2.01 \pm 0.25$ & $1.63 \pm 0.20$ & $1.75 \pm 0.22$ & $<0.05$ & $<0.001$ & ns \\
\hline CV (\%) & 11.17 & 12.47 & 12.09 & 12.44 & & & \\
\hline $\operatorname{Chl} b\left(\mathrm{mg} \mathrm{g}^{-1}\right)$ & $0.72 \pm 0.13$ & $0.66 \pm 0.16$ & $0.99 \pm 0.24$ & $0.83 \pm 0.19$ & $<0.001$ & $<0.001$ & ns \\
\hline CV (\%) & 18.03 & 24.08 & 24.57 & 23.08 & & & \\
\hline $\mathrm{N}(\%)$ & $3.81 \pm 0.29$ & $3.33 \pm 0.30$ & $3.42 \pm 0.33$ & $3.17 \pm 0.29$ & $<0.001$ & $<0.001$ & ns \\
\hline CV (\%) & 7.61 & 9.07 & 9.54 & 9.14 & & & \\
\hline
\end{tabular}

Note: Data are means of replicates \pm standard deviation. SPAD readings, chlorophyll meter readings; Chl, Chl $a$, and $\mathrm{Chl} b$, foliar mass-based chlorophyll, chlorophyll $a$, and chlorophyll $b$ content, respectively; N, foliar massbased nitrogen content; $\mathrm{CV}$, coefficient of variation; SPAD readings have no units; ns, nonsignificant.

Table 2. Correlation coefficients among indexes measured in tea leaves at plot and field scales in August and November, 2010. There were 16 sampling points at the plot scale $\left(100 \mathrm{~m}^{2}\right)$ and 50 sampling points at the field scale (32 ha).

\begin{tabular}{|c|c|c|c|c|c|c|c|c|}
\hline Scales & Month & & SPAD readings & $\mathbf{N}$ & Chl & Chl a & Chl b & Chl a/b \\
\hline \multirow{12}{*}{$\begin{array}{l}\text { Plot scale } \\
(n=16)\end{array}$} & \multirow{6}{*}{ August } & $\mathrm{N}$ & $0.53^{*}$ & & & & & \\
\hline & & $\mathrm{Chl}$ & $0.92^{* *}$ & $0.61^{* *}$ & & & & \\
\hline & & Chl $a$ & $0.90^{* *}$ & $0.62^{* *}$ & $0.99^{* *}$ & & & \\
\hline & & $\mathrm{Chl} b$ & $0.90^{* *}$ & $0.57^{*}$ & $0.97^{* *}$ & $0.93^{* *}$ & & \\
\hline & & $\mathrm{Chl} a / b$ & $-0.78^{* *}$ & -0.36 & $-0.81^{* *}$ & $-0.72^{* *}$ & $-0.91^{* *}$ & \\
\hline & & $\mathrm{Chl} / \mathrm{N}$ & $0.84^{* *}$ & 0.2 & $0.90^{* *}$ & $0.88^{* *}$ & $0.88^{* *}$ & $-0.80^{* *}$ \\
\hline & \multirow{6}{*}{ November } & $\mathrm{N}$ & 0.45 & & & & & \\
\hline & & $\mathrm{Chl}$ & $0.90^{* *}$ & $0.48^{*}$ & & & & \\
\hline & & Chl $a$ & $0.90^{* *}$ & $0.53^{*}$ & $0.99^{* *}$ & & & \\
\hline & & $\mathrm{Chl} b$ & $0.86^{* *}$ & 0.35 & $0.96^{* *}$ & $0.91^{* *}$ & & \\
\hline & & Chl $a / b$ & $-0.54^{*}$ & -0.05 & $-0.67^{* *}$ & $-0.56^{*}$ & $-0.84^{* *}$ & \\
\hline & & $\mathrm{Chl} / \mathrm{N}$ & $0.83^{* *}$ & 0.18 & $0.95^{* *}$ & $0.91^{* *}$ & $0.95^{* *}$ & $-0.76^{* *}$ \\
\hline
\end{tabular}


Continued...

\begin{tabular}{|c|c|c|c|c|c|c|c|c|}
\hline Scales & Month & & SPAD readings & $\mathbf{N}$ & Chl & Chl a & Chl b & Chl a/b \\
\hline \multirow{12}{*}{$\begin{array}{l}\text { Field scale } \\
(\mathrm{n}=50)\end{array}$} & \multirow{6}{*}{ August } & $\mathrm{N}$ & 0.21 & & & & & \\
\hline & & Chl & $0.88^{* *}$ & $0.37^{* *}$ & & & & \\
\hline & & Chl $a$ & $0.80^{* *}$ & $0.36^{* *}$ & $0.94^{* *}$ & & & \\
\hline & & Chl $b$ & $0.86^{* *}$ & $0.35^{*}$ & $0.96^{* *}$ & $0.82^{* *}$ & & \\
\hline & & Chl $a / b$ & $-0.81^{* *}$ & $-0.30^{*}$ & $-0.80^{* *}$ & $-0.59^{* *}$ & $-0.90^{* *}$ & \\
\hline & & $\mathrm{Chl} / \mathrm{N}$ & $0.81^{* *}$ & -0.22 & $0.82^{* *}$ & $0.77^{* *}$ & $0.80^{* *}$ & $-0.67^{* *}$ \\
\hline & \multirow{6}{*}{ November } & $\mathrm{N}$ & -0.14 & & & & & \\
\hline & & Chl & $0.84^{* *}$ & -0.1 & & & & \\
\hline & & Chl $a$ & $0.80^{* *}$ & -0.07 & $0.96^{* *}$ & & & \\
\hline & & Chl $b$ & $0.80^{* *}$ & -0.12 & $0.95^{* *}$ & $0.82^{* *}$ & & \\
\hline & & Chl $a / b$ & $-0.64^{* *}$ & 0.11 & $-0.74^{* *}$ & $-0.53^{* *}$ & $-0.90^{* *}$ & \\
\hline & & $\mathrm{Chl} / \mathrm{N}$ & $0.74^{* *}$ & $-0.61^{* *}$ & $0.84^{* *}$ & $0.78^{* *}$ & $0.82^{* *}$ & $-0.66^{* *}$ \\
\hline
\end{tabular}

Note: N, foliar mass-based nitrogen content (\%); Chl, Chl $a, \mathrm{Chl} b$, foliar mass-based chlorophyll, chlorophyll $a$ and chlorophyll $b$ content $\left(\mathrm{mg} \mathrm{g}^{-1}\right)$; Chl $a / b$, the ratio of chlorophyll $a$ and $b$ mass-based content; $\mathrm{Chl} / \mathrm{N}$, the ratio of chlorophyll and nitrogen mass-based content $\left(\mathrm{mg} \mathrm{g}^{-1}\right)$; SPAD readings and $\mathrm{Chl} a / b$ have no unit. * Significant at the 0.05 probability level, $* *$ Significant at the 0.01 probability level.

\subsection{Spatial variation in chlorophyll and nitrogen contents and SPAD readings}

There were significant spatial differences in the Chl $a$, Chl $b$, and $\mathrm{N}$ contents of tea leaves $(\mathrm{P}<0.001)$, but no significant differences in foliar Chl contents and SPAD readings were observed in space (Table 1). There were no significant temporal $\times$ spatial interactions for any of the foliar indexes. The coefficients of variation $(\mathrm{CV})$ of foliar $\mathrm{Chl}$ and $\mathrm{N}$ contents and SPAD readings in field-grown plants were greater than in plot-grown tea trees, which meant that these values fluctuated more when the spatial scale increased (Table 1). Foliar Chl $a$ and $\mathrm{N}$ contents in the plots were significantly higher than in the field, while foliar Chl $b$ contents in the plots were significantly lower than in the field. In general, the correlations between $\mathrm{Chl}, \mathrm{Chl}$ $a$, and $\mathrm{Chl} b$ contents, $\mathrm{Chl} / \mathrm{N}$ ratio, and SPAD readings of tea leaves were greater in the plots than in the field; the correlation coefficients decreased with increasing spatial scale (Table 2).

\subsection{Foliar Chl contents and SPAD readings}

There were strong curvilinear relationships between total foliar Chl contents and SPAD readings (Figure $1)$, with coefficients of determination ranging from 0.719 to $0.853(\mathrm{P}<0.001)$. The slopes increased at greater SPAD values. In both months (August and November) and at both scales (plot and field), foliar $\mathrm{Chl} a$ accounted for most of the Chl content, ranging from $62.21 \%$ to $75.28 \%$ (Table 1 ). The relationships between foliar Chl $a$ and $\mathrm{Chl} b$ contents and SPAD readings were similar to those between total $\mathrm{Chl}$ contents and SPAD readings. 


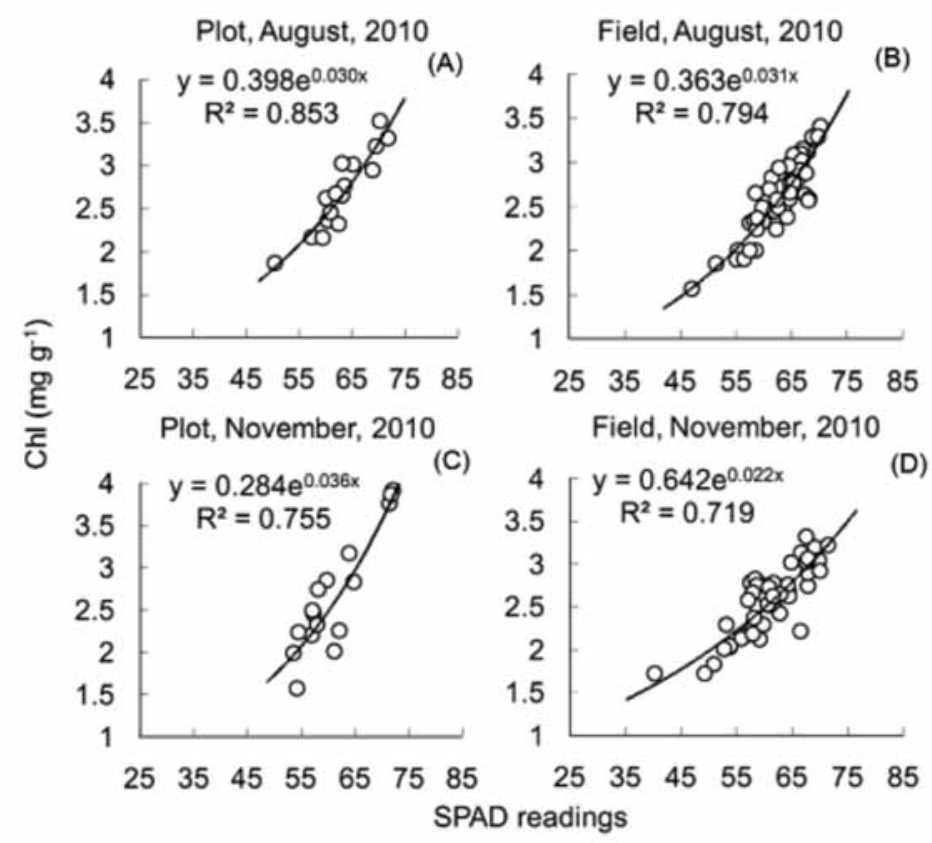

Figure 1. Relationships of foliar SPAD readings with chlorophyll (Chl) content in August (A and B) and November (C and D), 2010, at plot (A and C) and field (B and D) scales. There were 16 sampling points at plot scale $\left(100 \mathrm{~m}^{2}\right)$ and 50 sampling points at field scale (32 ha).

\subsection{Foliar $N$ contents and SPAD readings}

Nitrogen contents of tea leaves were significantly positively correlated with SPAD readings in the plots in August $(p<0.05)$ but not in November. Foliar N content and SPAD readings were not significantly correlated at the field scale (Table 2).

\subsection{Chl/N and SPAD readings}

There were significant correlations between foliar $\mathrm{N}$ and $\mathrm{Chl}$ contents at the plot scale in both August $(\mathrm{P}<0.01)$ and November $(p<0.05)$, but at the field scale they were only significantly correlated in August $(\mathrm{P}<0.01)$. Similar to the relationships between foliar $\mathrm{Chl}$ and SPAD readings, there was a strong exponential relationship between $\mathrm{Chl} / \mathrm{N}$ and SPAD readings (Figure 2), with coefficients of determination ranging from 0.595 to $0.723(p<0.001)$. 


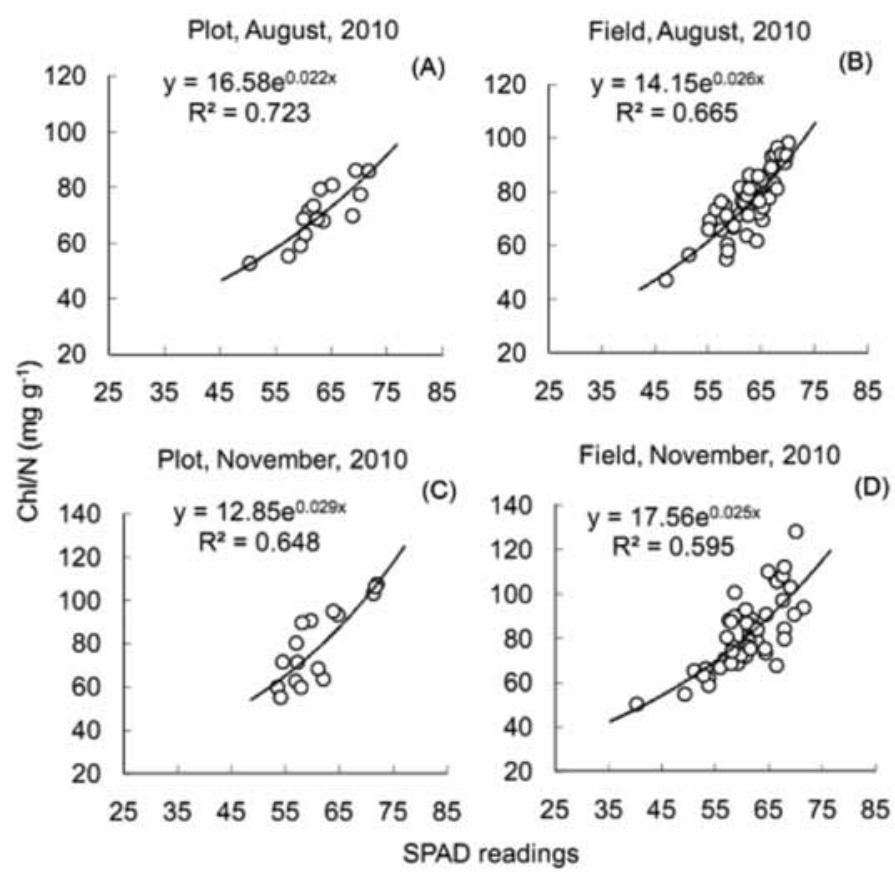

Figure 2. Relationships between foliar SPAD readings and chlorophyll/nitrogen $(\mathrm{Chl} / \mathrm{N}$ ) ratio in August (A and B) and November (C and D), 2010, at plot (A and C) and field (B and D) scales. There were 16 sampling points in plot scale $\left(100 \mathrm{~m}^{2}\right)$ and 50 sampling points at field scale $(32 \mathrm{ha})$.

\section{Discussion}

The relationships between $\mathrm{Chl}$ and SPAD readings were well described by an exponential function. This result was similar to previously-reported studies in other species (Marenco et al., 2009; Uddling et al., 2007). Temporal and spatial variation did not significantly affect foliar Chl contents, SPAD readings, or their relationships. These results indicated that SPAD readings could be used to estimate the relative $\mathrm{Chl}$ contents of tea leaves at different times and spatial scales.

The relationships between $\mathrm{N}$ contents and SPAD readings of tea leaves were not strong at the field level, nor in November at the plot level. This effect may have been due in part to heterogeneity in leaf thickness and foliar $\mathrm{N}$ distribution within a leaf (Chang and Robison, 2003). Additionally, nutrients other than $\mathrm{N}$ also affect $\mathrm{Chl}$ concentrations, which could further affect the applicability of SPAD readings to assess $\mathrm{N}$ nutrition status (Fritschi and Ray, 2007). Furthermore, nutritional status of other elements (Valenzuela et al., 1994), plant characteristics, environmental factors (Wang et al., 2004), and insect damage might all affect leaf $\mathrm{Chl}$ and $\mathrm{N}$ contents and therefore foliar SPAD readings.

The $\mathrm{Chl} / \mathrm{N}$ ratio indicates the proportion of $\mathrm{N}$ allocated to $\mathrm{Chl}$ at the expense of other macromolecules, such as rubisco, other proteins, nucleic acids, free amino acids, and secondary metabolites (Martin 
et al., 2007; Rozendaal et al., 2006). Plants alter how they partition $\mathrm{N}$ within the photosynthetic apparatus depending on growth conditions, e.g., the light environment (Kitaoka and Koike, 2004). In shaded conditions, more leaf $\mathrm{N}$ is allocated to $\mathrm{Chl}$ to enhance light capture, whereas, in sunny conditions, more leaf $\mathrm{N}$ is invested in Rubisco to increase carbon fixation (Kimura et al., 1998). Evergreen plants like tea undergo substantial changes in light and temperature conditions over the course of a year, and these changes may affect nitrogen partitioning (Muller et al., 2005). Therefore, these factors may cause temporal and spatial variation in the relationship between foliar $\mathrm{N}$ contents and SPAD readings. Additional research will be required to clarify how the relationship between $\mathrm{N}$ content and SPAD readings of tea leaves changes in space and time.

\section{Conclusions}

In conclusion, SPAD readings could estimate foliar $\mathrm{Chl}$ contents of tea plants in space and time. However, spatial and temporal differences must be considered when using SPAD readings to directly estimate foliar $\mathrm{N}$ contents of tea plants. SPAD readings could be used to optimize fertilizer application in tea plantations if a stable relationship between foliar $\mathrm{N}$ content and SPAD readings could be identified. Further research is required to explore the relationship between foliar $\mathrm{N}$ contents and SPAD readings for tea plants.

\section{Acknowledgements}

This project was financially supported by the National Water Project of China (2008ZX07101-006-02). The authors thank Jingshan Shenlong Tea Co., Ltd., and Mrs. Mao Lijuan of the Institute of Agrobiology and Environmental Science, Zhejiang University, for experimental support. We also thank Dr. Li Jinwen of
Shanghai Jiao Tong University for helpful discussions and review.

\section{References}

Abdelhamid, M., T. Horiuchi, and S. Oba. 2003. Evaluation of the SPAD value in faba bean (Vicia faba L.) leaves in relation to different fertilizer applications. Plant Production Science 6, 185-189.

Arnon, DI. 1949. Copper enzymes in isolated chloroplasts. Polyphenoloxidase in Beta vulgaris. Plant Physiol 24, 1-15.

Campbell, RJ, KN Mobley, RP Marini, and DG Pfeiffer. 1990. Growing conditions alter the relationship between SPAD-501 values and apple leaf chlorophyll. HortScience 25, 330-331.

Chang, S.X., and D.J. Robison. 2003. Nondestructive and rapid estimation of hardwood foliar nitrogen status using the SPAD-502 chlorophyll meter. Forest Ecology and Management 181, 331-338.

Chapman, S.C., and H.J. Barreto. 1997. Using a chlorophyll meter to estimate specific leaf nitrogen of tropical maize during vegetative growth. Agronomy Journal 89, 557-562.

Costa, C., L.M. Dwyer, P. Dutilleul, D.W. Stewart, B. Luo, and D.L. Smith. 2001. Inter-relationships of applied nitrogen, SPAD, and yield of leafy and non-leafy maize genotypes. Journal of plant nutrition 24, 1173-1194.

Denuit, J.P., M. Olivier, M.J. Goffaux, J.L. Herman, J.P. Goffart, J.P. Destain, and M. Frankinet. 2002. Management of nitrogen fertilization of winter wheat and potato crops using the chlorophyll meter for crop nitrogen status assessment. Agronomie 22, 847-853.

Errebhi, M., C.J. Rosen, S.C. Gupta, and D.E. Birong. 1998. Potato yield response and nitrate leaching as influenced by nitrogen management. Agronomy Journal 90, 10-15. 
Evans, JR. 1989. Partitioning of nitrogen between and within leaves grown under different irradiances. Functional Plant Biology 16, 533-548.

Fritschi, FB, and JD Ray. 2007. Soybean leaf nitrogen, chlorophyll content, and chlorophyll a/b ratio. Photosynthetica 45, 92-98.

Hoel, B.O. 2002. Chlorophyll meter readings in winter wheat: cultivar differences and prediction of grain protein content. Acta Agriculturae Scandinavica, Section B-Plant Soil Science 52, 147-157.

Huang, J., F. He, K. Cui, R.J. Buresh, B. Xu, W. Gong, and S. Peng. 2008. Determination of optimal nitrogen rate for rice varieties using a chlorophyll meter. Field Crops Research 105, 70-80.

Jaynes, DB, TS Colvin, DL Karlen, CA Cambardella, and DW Meek. 2001. Nitrate loss in subsurface drainage as affected by nitrogen fertilizer rate. Journal of Environmental Quality 30, 1305-1314.

Jinwen, L., Y. Jingping, F. Pinpin, S. Junlan, L. Dongsheng, G. Changshui, and C. Wenyue. 2009. Responses of rice leaf thickness, SPAD readings and chlorophyll $\mathrm{a} / \mathrm{b}$ ratios to different nitrogen supply rates in paddy field. Field Crops Research 114, 426-432.

Jung, S., DA Rickert, NA Deak, ED Aldin, J. Recknor, LA Johnson, and PA Murphy. 2003. Comparison of Kjeldahl and Dumas methods for determining protein contents of soybean products. Journal of the American Oil Chemists' Society 80, 11691173 .

Kamau, DM, J.H.J. Spiertz, and O. Oenema. 2008. Carbon and nutrient stocks of tea plantations differing in age, genotype and plant population density. Plant and Soil 307, 29-39.

Kimura, K., A. Ishida, A. Uemura, Y. Matsumoto, and I. Terashima. 1998. Effects of current-year and previous-year PPFDs on shoot gross morphology and leaf properties in Fagus japonica. Tree physiology 18, 459-466.
Kitaoka, S., and T. Koike. 2004. Invasion of broadC) leaf tree species into a larch plantation: seasonal light environment, photosynthesis and nitrogen allocation. Physiologia Plantarum 121, 604-611.

Le Bail, M., M.H. Jeuffroy, C. Bouchard, and A. Barbottin. 2005. Is it possible to forecast the grain quality and yield of different varieties of winter wheat from Minolta SPAD meter measurements? European Journal of Agronomy 23, 379-391.

Lin, F.F., L.F. Qiu, J.S. Deng, Y.Y. Shi, L.S. Chen, and K. Wang. 2010. Investigation of SPAD meterbased indices for estimating rice nitrogen status. Computers and Electronics in Agriculture 71, 6065.

Marenco, RA, SA Antezana-Vera, and HCS Nascimento. 2009. Relationship between specific leaf area, leaf thickness, leaf water content and SPAD502 readings in six Amazonian tree species. Photosynthetica 47, 184-190.

Martin, R.E., G.P. Asner, and L. Sack. 2007. Genetic variation in leaf pigment, optical and photosynthetic function among diverse phenotypes of Metrosideros polymorpha grown in a common garden. Oecologia 151, 387-400.

Muller, O., K. Hikosaka, and T. Hirose. 2005. Seasonal changes in light and temperature affect the balance between light harvesting and light utilisation components of photosynthesis in an evergreen understory shrub. Oecologia 143, 501-508.

Rozendaal, DMA, VH Hurtado, and L. Poorter. 2006. Plasticity in leaf traits of 38 tropical tree species in response to light; relationships with light demand and adult stature. Functional Ecology 20, 207-216.

Schaper, H., and EK Chacko. 1991. Relation between extractable chlorophyll and portable chlorophyll meter readings in leaves of eight (sub-) tropical fruit tree species. Journal of Plant Physiology 138, 674-677. 
Uddling, J., J. Gelang-Alfredsson, K. Piikki, and H. Pleijel. 2007. Evaluating the relationship between leaf chlorophyll concentration and SPAD-502 chlorophyll meter readings. Photosynthesis Research 91, 37-46.

Valenzuela, JL, A. Sanchez, and L. Romero. 1994. Influence of nitrogen, phosphorus, and potassium fertilization on foliar pigments in muskmelon plants. Communications in Soil Science and Plant Analysis 25, 1595-1604.
Venkatesan, S., and MNK Ganapathy. 2004. Impact of nitrogen and potassium fertiliser application on quality of CTC teas. Food Chemistry 84, 325-328.

Wang, Q., J. Chen, and Y. Li. 2004. Nondestructive and rapid estimation of leaf chlorophyll and nitrogen status of peace lily using a chlorophyll meter. Journal of plant nutrition 27, 557-569.

Zvomuya, F.R., C.J. Russelle, M.P. Gupta, and C. Satish. 2003. Nitrate leaching and nitrogen recovery following application of polyolefin-coated urea to potato. Journal of Environmental Quality 32, 480-489. 